\title{
Rabbit Pancreatic B Cell. Morphological and Functional Studies during Embryonal and Post-Natal Development*
}

\author{
S. A. Bencosme, M. B. Wilson, H. Aleyassine, A. J. de Bold, and M. L. de Bold \\ Department of Pathology, Queen's University and the Kingston General Hospital, Kingston, Ontario, Canada
}

Received: October 22, 1969

\begin{abstract}
Summary. Aldehyde-fuchsin-positive B granules were found in rabbits ranging from 24-day embryos to adult animals. Ultrastructurally, the B granules were of two types: dark and pale; they displayed different fixation properties. The granules of foetal and neonatal rabbits were almost exclusively of the pale type and were distributed mainly along the cell border. B cells from older rabbits showed a progressive increase in the number of granules and in the proportion of dark to pale granules; they also showed changes in the granule distribution pattern. Despite morphological differences, the pancreases from 24-day embryos, 30-day embryos, and adult rabbits all showed a significant insulin release in response to glucose challenge in vitro. Non-necrotic B cells from pancreas after glucose challenge presented no obvious changes in aldehyde-fuchsin positivity, granule distribution, proportion of dark to pale granules, or the extent of emiocytosis.
\end{abstract}

Cellule $B$ de pancréas de lapin. Etude morphologique et fonctionnelle au cours du développement embryonnaire et post-natal

Résumé. Les granules B réagissant positivement à l'aldéhyde-fuchsine, peuvent être mis en évidence dans le pancréas de lapin à partir du vingt-quatrième jour de la vie embryonnaire jusqu'à l'âge adulte. On peut identifier en microscopie électronique deux types de granules $B$ avec des propriétés de fixation différente: granules denses et granules clairs. Dans le foetus ou le nouveau-né de lapin les granules sont presque exclusivement du type clair et situés principalement à la périphérie de la cellule. Plus tard, à un âge plus avancé, on constate une augmentation progressive des granules denses par rapport aux granules clairs, ainsi qu'un accroissement du degré de granulation et un changement dans la distribution eytoplasmique des granules. Malgré les différences morphologiques, la libération d'insuline par le pancréas foetal et celui de l'adulte, incubés dans les conditions in vitro, a été augmentée d'une façon significative en présence de concentration élevée de glucose. Cependant, l'étude morphologique des cellules $B$ du pancréas, après l'incubation, n'a pas pu révéler des changements évidents dans la positivité à l'aldéhyde-fuchsine, la distribution ou la proportion des deux types de granules, ou dans le degré de l'émiocytose.

Morphologische und funltionelle Studien von B-Zellen im Kaninchenpankreas während der embryonalen und postnatalen Entwicklung

Zusammenfassung. Vom 24 Tage alten Kaninchenembryo bis zum erwachsenen Tier wurden aldehydfuchsinpositive B-Granula gefunden. Elektronenmikroskopisch unterscheiden wir zwei Typen von Granula, helle und dunkle, die verschiedene Fixationseigenheiten darstellen. Die Granula von foetalen und neugeborenen Kaninchen waren fast ausschließlich vom hellen Typ und vornehmlich entlang dem Zellrand verteilt. B-Zellen von älteren Kaninchen zeigen die fortschreitende Erhöhung der Proportion dunkler zu heller Granula, sowie eine allmähliche Zunahme und Veränderung in der Anordnung der Granula. Trotz morphologischer Unterschiede reagieren Pankreata von 24 Tage alten Embryos, 30 Tage alten Embryos und von erwachsenen Kaninchen mit einer deutlichen Insulinfreisetzung bei Glucosestimulation in vitro. Jedoch ergaben Untersuchungen von nicht nekrotischen B-Zellen beim inkubierten. Pankreas keine deutliche Änderung in der Aldehydefuchsinpositivität, Granulaverteilung, im Verhältnis von dunklen zu hellen Granula und dem Ausmaß der Emiocytosis.

Key-words: B cell development, rabbit, pancreatic is lets, embryo, aldehyde-fuchsin, electron microscopy, B granules, fixation, insulin release in vitro, glucose challenge, necrotic B cells.

\section{Introduction}

Although advances have been made in the understanding of the mechanism of insulin release in vitro, there appears to be a lack of agreement on the relationship between the biochemical and morphological correlates of the process $[7,9,11,12,26,54]$. It has been shown that $B$ cells contain two types of secretory granules, dark and pale $[3,22,23,25,50]$. Both types are aldehyde-fuchsin positive $[3,23]$ and appear to contain insulin $[35,50]$. However, their respective roles in insulin release in vitro have yet to be clarified. It is of great interest that, despite the absence of aldehydefuchsin-positive granules [15,37], the 27-day foetal

* Portions of this work were presented at the Meeting of the American Society for Cell Biology, Denver, Colorado, November $13,1967$. rabbit pancreas responds to glucose challenge in vitro [37]. These observations suggest that the morphological expression of insulin release in the foetus may differ from that in the adult.

A study of the roles of the dark and pale granules in insulin release in vitro would be advantageously investigated in the rabbit since $B$ cells of this species contain a large number of both granule types [3, 23]. Moreover, in neonatal rabbits, pale $B$ granules have been shown to be especially abundant [23]. To our knowledge, no ultrastructural study of foetal rabbit pancreas has been reported.

In the present work, a comparative morphological and functional study of the $\mathrm{B}$ cell was undertaken in the rabbit with special reference to the dark and pale secretory granules. For this purpose, we did a corre- 
lative light and electron microscopic investigation of the development of foetal and postnatal B cells, beginning with embryos 24 days old. Against this background, we then studied in vitro the insulin release response to glucose challenge in foetal (24- and 30-dayold) and adult pancreas.

\section{Materials and Methods}

Animals. For the developmental study, 40 embryos ranging in age from 24 to 32 days and 71 postnatal rabbits ranging from twelve hours to one year old
Both fixatives contained one drop of $1 \% \mathrm{CaCl}_{2}$ per 10 ml. After ethanol dehydration, the tissues were embedded in Epon 812 [29]. Sections were cut on an LKB Ultratome. Thick sections (approx. $1 \mu$ ) were stained with toluidine blue for locating the islets and with aldehyde-fuchsin [9] to study the specific granules. Thin sections (approx. $400 \AA$ to $800 \AA$ ) were doubly stained with uranyl acetate [44] and lead citrate [47], and examined on an RCA EMU-3D or Hitachi HU$11 \mathrm{C}$ electron microscope.

Incubation Media. The basic medium was a bicarbonate-buffered salt solution [18] supplemented with

Table 1. Insulin release in vitro by 24 -day foetal rabbit pancreas, $\mu U / \mathrm{ml} / 30 \mathrm{~min}$

\begin{tabular}{|c|c|c|c|c|c|c|}
\hline \multirow{2}{*}{$\begin{array}{l}\text { Experi- } \\
\text { ment }\end{array}$} & \multirow{2}{*}{$\begin{array}{l}\text { Time period } \\
(30 \text { min each) }\end{array}$} & \multicolumn{2}{|c|}{ Control flasksa } & \multicolumn{3}{|c|}{ Test flasks ${ }^{b}$} \\
\hline & & A & B & $\mathrm{C}$ & $\mathrm{D}$ & $\mathbf{E}$ \\
\hline \multirow[t]{5}{*}{1} & I & 98 & 106 & 82 & 86 & 92 \\
\hline & II & 148 & 140 & 164 & 164 & 180 \\
\hline & III & 150 & 138 & - & - & - \\
\hline & IV & 122 & 100 & 100 & 114 & 114 \\
\hline & $\mathrm{V}$ & 92 & 98 & 110 & 132 & 134 \\
\hline \multirow{5}{*}{2} & $I$ & 40 & 16 & 20 & 14 & \\
\hline & II & 26 & 16 & 89 & 70 & \\
\hline & III & 36 & 20 & - & - & \\
\hline & IV & 50 & 14 & 59 & 21 & \\
\hline & V & 50 & 14 & 80 & 59 & \\
\hline \multirow[t]{5}{*}{3} & I & 50 & 51 & 100 & 125 & 73 \\
\hline & II & 45 & 78 & 111. & 136 & 127 \\
\hline & III & 45 & 71 & - & - & - \\
\hline & IV & 68 & 63 & 100 & 50 & 85 \\
\hline & V & 70 & 58 & 103 & 128 & 95 \\
\hline \multirow[t]{5}{*}{4} & I & 34 & 93 & 51 & 75 & \\
\hline & II & 65 & 108 & 64 & 113 & \\
\hline & III & 93 & 84 & - & - & \\
\hline & IV & 69 & 98 & 61 & 69 & \\
\hline & $\mathrm{V}$ & 64 & 96 & 114 & 91 & \\
\hline
\end{tabular}

a Incubated in low glucose throughout time periods I to $\mathrm{V}$.

b Incubated in low glucose during time periods I, III, IV, and in high glucose during time periods II and $\nabla$. Media from time period III were not assayed for insulin.

were used. For the study in vitro, eighteen 24-day embryos, sixteen 30-day embryos, and three adult rabbits were used. Embryos were removed after their mothers were anaesthetized with Nembutal. The splenic portion of the pancreas was taken after the rabbits were killed with Nembutal or, in the case of the embryos, by decapitation. The ages of the embryos were dated from the observed mating time.

Light Microscopy. Tissues were fixed in $10 \%$ formalin, Zenker-formol, and Bouin's fixatives. Twomicron-thick paraffin embedded sections were stained with aldehyde-fuchsin counterstained with a trichrome [14], modified Masson's trichrome [1], and Gomori's chrome-alum hematoxylin [1].

Electron Microscopy. Two fixation methods were used: (I) two hours in 3\% glutaraldehyde in Sorensen's $0.1 \mathrm{M}$ phosphate buffer $\mathrm{pH} 7.4$ [43], washed with Sorensen's phosphate buffer containing $10 \%$ sucrose for $30 \mathrm{~min}$, and post-fixed for two hours in $2 \% \mathrm{OsO}_{4}$ in the same buffer without sucrose; (II) two hours in $2 \% \mathrm{OsO}_{4}$ in Sorensen's $0.1 \mathrm{M}$ phosphate buffer $\mathrm{pH} 7.4$.
$5 \mathrm{mM}$ sodium fumarate and $5 \mathrm{mM}$ sodium glutamate. Glucose was added to yield media with two different glucose concentrations, $0.3 \mathrm{mg} / \mathrm{ml}$ (low) and $4.0 \mathrm{mg} / \mathrm{ml}$ (high). The gas phase was oxygen and carbon dioxide $(95: 5)$.

In Vitro Experimental Design. The incubation procedure was essentially that of Coore and Randle [6]. In each experiment, either one adult or up to six embryo litter-mates were used. Six portions of adult pancreas or six embryonal pancreases were placed in six separate flasks each containing $5 \mathrm{ml}$ incubation medium of low glucose concentration. After a 30-min preincubation period, the tissues were incubated at $37^{\circ} \mathrm{C}$ with shaking for five consecutive time periods of $30 \mathrm{~min}$ each ( $\mathrm{I}$ to $\mathrm{V}$, Tables 1 to 3 ). Two of the flasks were used as controls and were incubated in the presence of glucose at low concentration during the five time periods. The remaining four flasks (test flasks) were incubated in the presence of high glucose concentration during time periods II and $\vec{V}$, and in the presence of low glucose during time periods I, III, and IV. 
Prior to each incubation experiment involving an adult rabbit, some of the pancreatic tissue was fixed for light and electron microscopic studies. In the case of the embryos, one or two additional litter-mates were used for morphological control. After incubation, the tissues were fixed for light and electron microscopy.

The pre-incubation period and time period III for the four test flasks were considered equilibration periods, and thus the incubation media used for them were not assayed for insulin content. The remaining incubation media were centrifuged $20 \mathrm{~min}$ at $500 \times g$ and $4^{\circ} \mathrm{C}$. The supernatants were then assayed for insulin. expressed in terms of the insulin release ratio, $R$, given below.

$$
R=\frac{I_{t}}{I_{c}} \times \frac{I_{c} \text { ave. }}{I_{t} \text { ave. }}
$$

Where $I_{t} \quad=$ insulin release in the test flask during a particular time period.

$I_{e} \quad=$ insulin release in the control flasks (averaged together) during the same time period as $I_{t}$ above.

$I_{c}$ ave. $=$ average insulin release in control flasks during the 5 measured time periods.

$I_{t}$ ave. $=$ average insulin release in the test flasks during the 4 measured time periods.

Table 2. Insulin release in vitro by 30 -day foetal rabbit pancreas, $\mu U / \mathrm{ml} / 30 \mathrm{~min}$

\begin{tabular}{|c|c|c|c|c|c|c|c|}
\hline \multirow{2}{*}{$\begin{array}{l}\text { Experi- } \\
\text { ment }\end{array}$} & \multirow{2}{*}{$\begin{array}{l}\text { Time period } \\
(30 \mathrm{~min} \text { each })\end{array}$} & \multicolumn{2}{|c|}{ Control flasks } & \multicolumn{4}{|c|}{ Test flasksb } \\
\hline & & A & B & $\mathrm{C}$ & $\mathrm{D}$ & $\mathrm{E}$ & $\mathbf{F}$ \\
\hline \multirow[t]{5}{*}{1} & I & 138 & 176 & 25 & 62 & 73 & 78 \\
\hline & II & 84 & 153 & 65 & 116 & 153 & 340 \\
\hline & III & 105 & 191. & - & - & - & - \\
\hline & IV & 91 & 198 & 75 & 77 & 138 & 160 \\
\hline & V & 143 & 170 & 138 & 288 & 219 & 290 \\
\hline \multirow[t]{5}{*}{2} & I & 118 & 177 & 180 & 226 & 180 & 263 \\
\hline & II & 196 & 190 & 404 & 365 & 374 & 642 \\
\hline & III & 113 & 114 & - & - & - & - \\
\hline & IV & 118 & 154 & 150 & 194 & 156 & 108 \\
\hline & $\mathrm{V}$ & 135 & 160 & 315 & 452 & 363 & 230 \\
\hline \multirow[t]{5}{*}{3} & I & 110 & 105 & 45 & 100 & & \\
\hline & II & 133 & 113 & 125 & 170 & & \\
\hline & III & 134 & 210 & - & - & & \\
\hline & IV & 62 & 111 & 10 & 85 & & \\
\hline & $\mathrm{V}$ & 50 & 88 & 48 & 215 & & \\
\hline
\end{tabular}

a Incubated in low glucose throughout time periods I to $\mathrm{V}$.

b Incubated in low glucose during time periods I, III, IV, and in high glucose during time periods II and V. Media from time period. III were not assayed for insulin.

Table 3. Insulin release in vitro by adult rabbit pancreas, $\mu U / \mathrm{ml} / 30 \mathrm{~min}$

\begin{tabular}{|c|c|c|c|c|c|c|c|}
\hline Experi- & Time period & Con & flasks ${ }^{a}$ & & Test & $\mathrm{ks}^{\mathrm{b}}$ & \\
\hline ment & (30 min each) & A & $\mathrm{B}$ & $\mathrm{C}$ & $\mathrm{D}$ & $\mathbf{E}$ & $\mathrm{F}$ \\
\hline 1 & $I$ & 81 & 108 & 108 & 118 & 81 & 36 \\
\hline & II & 225 & 201 & 249 & 253 & 261 & 221 \\
\hline & III & 162 & 148 & - & - & - & - \\
\hline & IV & 123 & 58 & 50 & 30 & 35 & 29 \\
\hline & $\mathrm{V}$ & 210 & 232 & 115 & 135 & 258 & 300 \\
\hline 2 & $\mathrm{I}$ & 56 & 80 & 113 & 159 & 147 & 80 \\
\hline & II & 56 & 80 & 291 & 300 & 300 & 300 \\
\hline & III & 56 & 125 & - & - & - & - \\
\hline & $\mathrm{IV}$ & 15 & 62 & 146 & 203 & 178 & 66 \\
\hline & V & 66 & 56 & 200 & 300 & 300 & 143 \\
\hline 3 & $I$ & 58 & 88 & 28 & & & \\
\hline & II & 58 & 80 & 203 & & & \\
\hline & IIII & 73 & 38 & - & & & \\
\hline & IV & 53 & 49 & 24 & & & \\
\hline & $V$ & 58 & 25 & 154 & & & \\
\hline
\end{tabular}

a Incubated in low glucose throughout time periods $I$ to $V$.

b Incubated in low glucose during time periods I, III, IV, and in high glucose during time periods II and V. Media from time period III were not assayed for insulin.

Measurement of Insulin. The insulin content of the incubation media was measured by radio-immunoassay [17].

Expression of In Vitro Results. The insulin release in each test flask during a particular time period was
It should be noted that the factor $\frac{I_{c} \text { ave. }}{I_{k} \text { ave. }}$ in the $R$ ratio corrects for variations in insulin release due to different amounts of islet tissue in the flasks being considered. The use of this correction factor allowed 
the $R$ values for each of the four studied time periods to be averaged ( $\bar{R}_{\mathrm{I}}, \bar{R}_{\mathrm{II}}, \bar{R}_{\mathrm{IV}}$, and $\bar{R}_{\mathrm{V}}$ ) for each age group. Analysis of variance showed that for animals of the same age, pooled variance could be used. The variance was consequently pooled, and mean insulin release ratios were plotted against time. The significance of the difference between the ratios from both the high glucose time period and the low glucose time period was determined using Student's $t$ test.

\section{Results}

\section{Light Microscopy}

A detailed description of the histogenesis of rabbit pancreatic islets has been previously reported using Masson's trichrome and Gomori's chrome-alum hematoxylin stains [2]. The additional use of aldehydefuchsin, a highly selective stain for B granules, has enabled us, in the present work, to further characterize foetal B cells with respect to their secretory granules.

In the 24- and 25-day embryos, the majority of A, $B$, and $D$ cells, as recognized by the specific staining of their granules, were found scattered either singly or in small clusters within the walls of acini and ducts (Fig. 1). In addition, a few small islets were present. From the 26th day of foetal life onwards, numerous islets were seen (Figs. 2, 3).

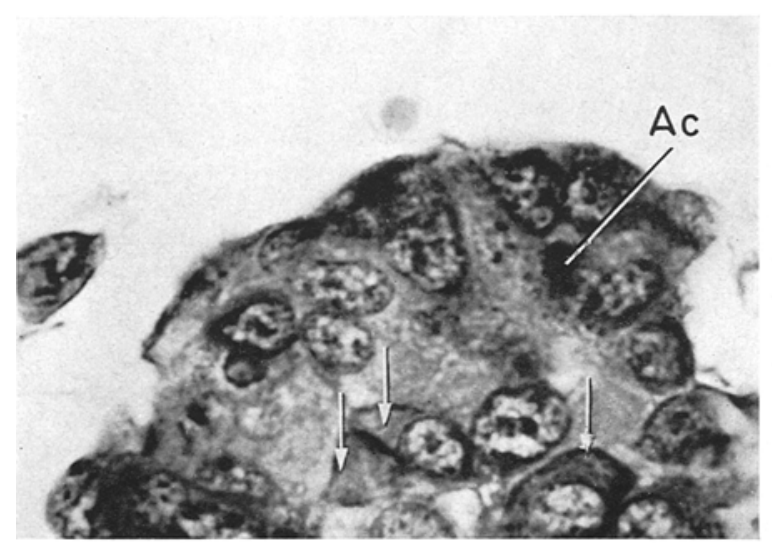

Fig. 1. 24-day embryo. B cells with margination of granules $(\rightarrow)$. Portion of an acinus (Ac) with zymogen granules. Zenker-formol fixation. Aldehyde-fuchsin stain. $\times 1240$

Islet maturity with respect to size, proportion of cell types, and capillarization was not reached until long after birth. Sections of the pancreatic islets of 26-day embryos usually contained only about 5 to 10 nuclei per islet. The number of cells per islet increased with age; however, no appreciable increase in islet size was observed in animals over 90 days old. The proportion of $B: A: D$ cells progressively changed from about 55:20:25 in late foetal and newborn rabbits to about $75: 20: 5$ in the 60-day-old and older rabbits. Between 30 and 60 days post partum, capillarization of the islets was seen to have increased greatly. This process appeared to be complete by 100 days after birth.
Aldehyde-fuchsin-positive B granules in foetal pancreas were located almost exclusively along the entire $B$ cell circumference regardless of whether these cells were scattered within the walls of acini or were part of a well-formed islet. Only a few B cells resembled those of the adult and contained a large number of granules. In rabbits 1 to 7 days of age, the majority of $B$ cells exhibited margination of their granules similar to that of embryonal B cell. With time, however, the number of $\mathbf{B}$ granules increased, and the distribution changed with the development of the islet capillary bed (Figs. 2-4). This latter process resulted in a greater number of B cells with a capillary pole. A progressive accumulation of B granules occurred at these capillary poles. In animals over 90 days of age, the capillary polarization of the B granules was less apparent because of the "overflow" of granules into the rest of the cytoplasm.

In contrast to the high affinity of the aldehydefuchsin stain for the $\mathbf{B}$ granules in both adult and foetal pancreas, Gomori's chrome-alum hematoxylin clearly differentiated these granules from the rest of the cytoplasm only in animals over 7 days post partum. Interestingly, the aldehyde-fuchsin was frequently seen to stain also the zymogen granules of the acinar cells of foetal pancreas. Because of the great difference

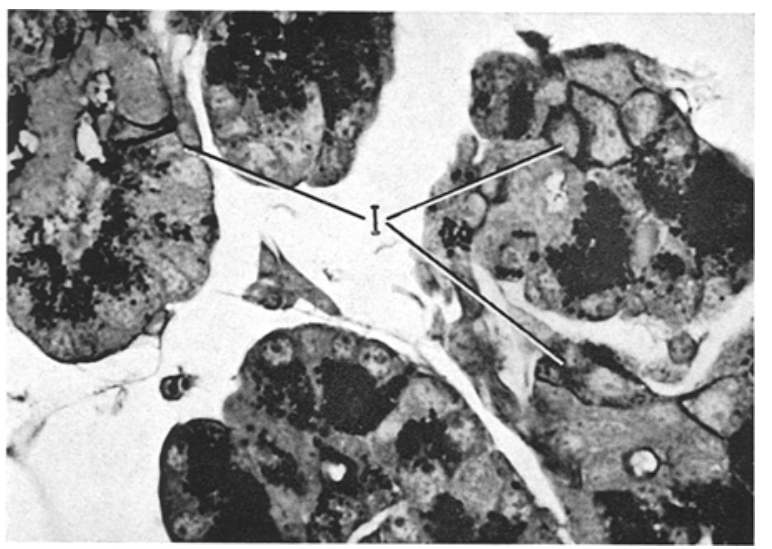

Fig. 2. 26-day embryo. Portions of 3 small islets (I). Zenker-formol fixation. Aldehyde-fuchsin stain. $\times 620$

in granule size and distribution, however, this staining similarity of zymogen and B granules did not cause confusion in distinguishing the two cell types.

A cells were commonly seen in foetal pancreas. Of all stains used, aldehyde-fuchsin counterstained with trichrome most clearly distinguished A cells from B cells. $D$ cells were best identified in both foetal and postnatal pancreas when Masson's trichrome was used. During the first few weeks of postnatal life, the D cells were frequently seen clustered (e. g. 10 to 25 ) at one pole of the islet.

\section{Electron Microscopy}

Previous studies have established the fine structure of $\mathrm{OsO}_{4}$-fixed adult $[11,19,33,39]$ and neonatal [23, 


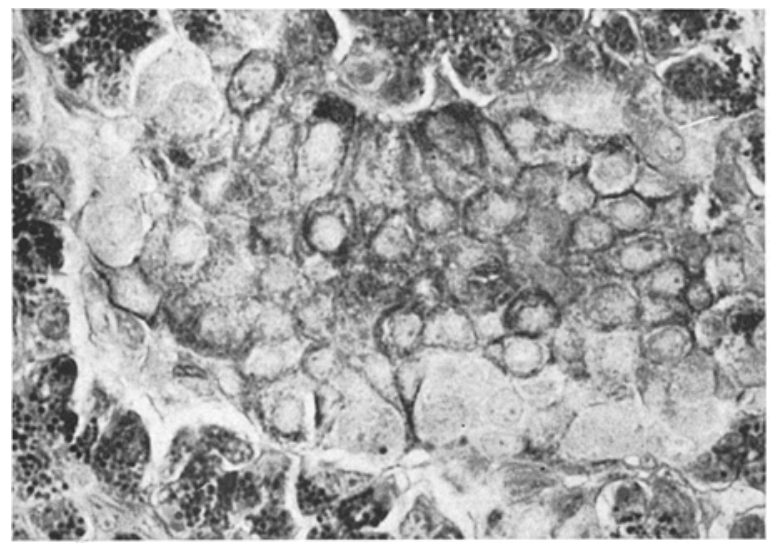

Fig. 3. 28-day-old rabbit. Well-formed pancreatic islet. Margination of $\mathrm{B}$ granules is still very common. Zenkerformol fixation. Aldehyde-fuchsin stain. $\times 620$

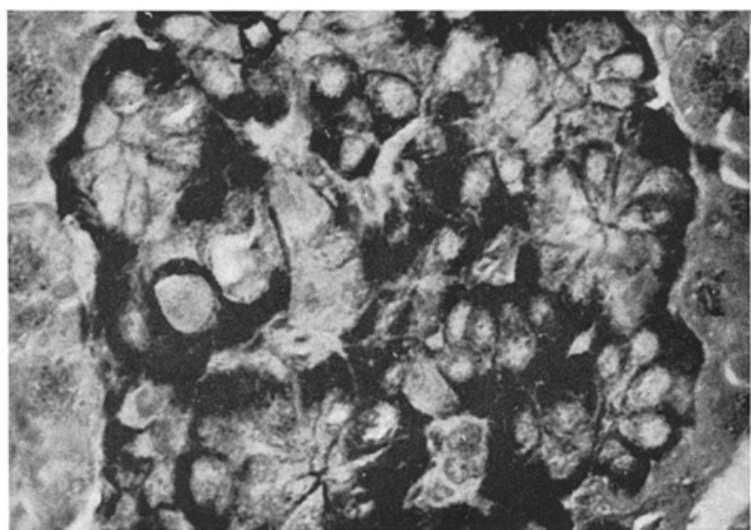

Fig. 4. Adult rabbit islet with well-granulated B cells. Zenker-formol fixation. Aldehyde-fuchsin stain. $\times 620$

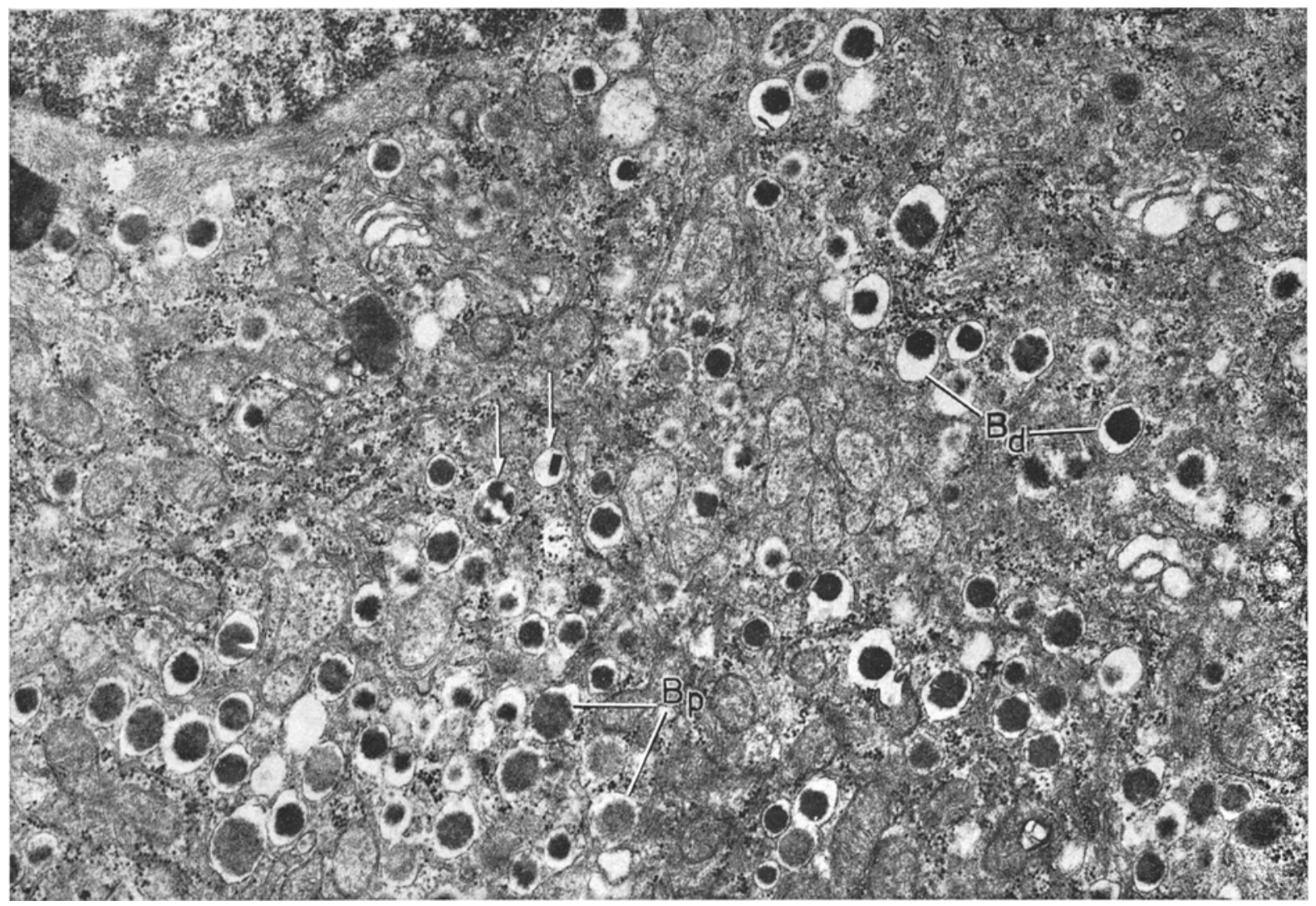

Fig. 5. Portions of typical adult $\mathrm{B}$ cells with dark $\left(B_{\tilde{d}}\right)$ and pale $\left(B_{p}\right)$ secretory granules. Occasional crystalloid cores $(\rightarrow)$ are seen. Glutaraldehyde-O $\mathrm{SO}_{4}$ fixation. $\times 18500$

50] rabbit pancreatic islet cells and of glutaraldehyde$\mathrm{OsO}_{4}$-fixed adult $[13,40]$ rabbit islet cells. Comparative study using both these fixation methods revealed in normal and cortisone-treated rabbits the presence of two types of B granules: dark and pale [3]. The pale granules were best preserved with the glutaraldehyde$\mathrm{OsO}_{4}$ procedure.
A typical adult rabbit $B$ cell, as found in glutaraldehyde-OsO ${ }_{4}$-fixed pancreas is seen in Fig. 5. The cytoplasm contains many dark and pale secretory granules in an approximate proportion of $1: 1$. The core of the dark B granules is surrounded by a clear space. The diameter of the pale B granules appears similar to that of the dark granules or slightly larger; but the pale 

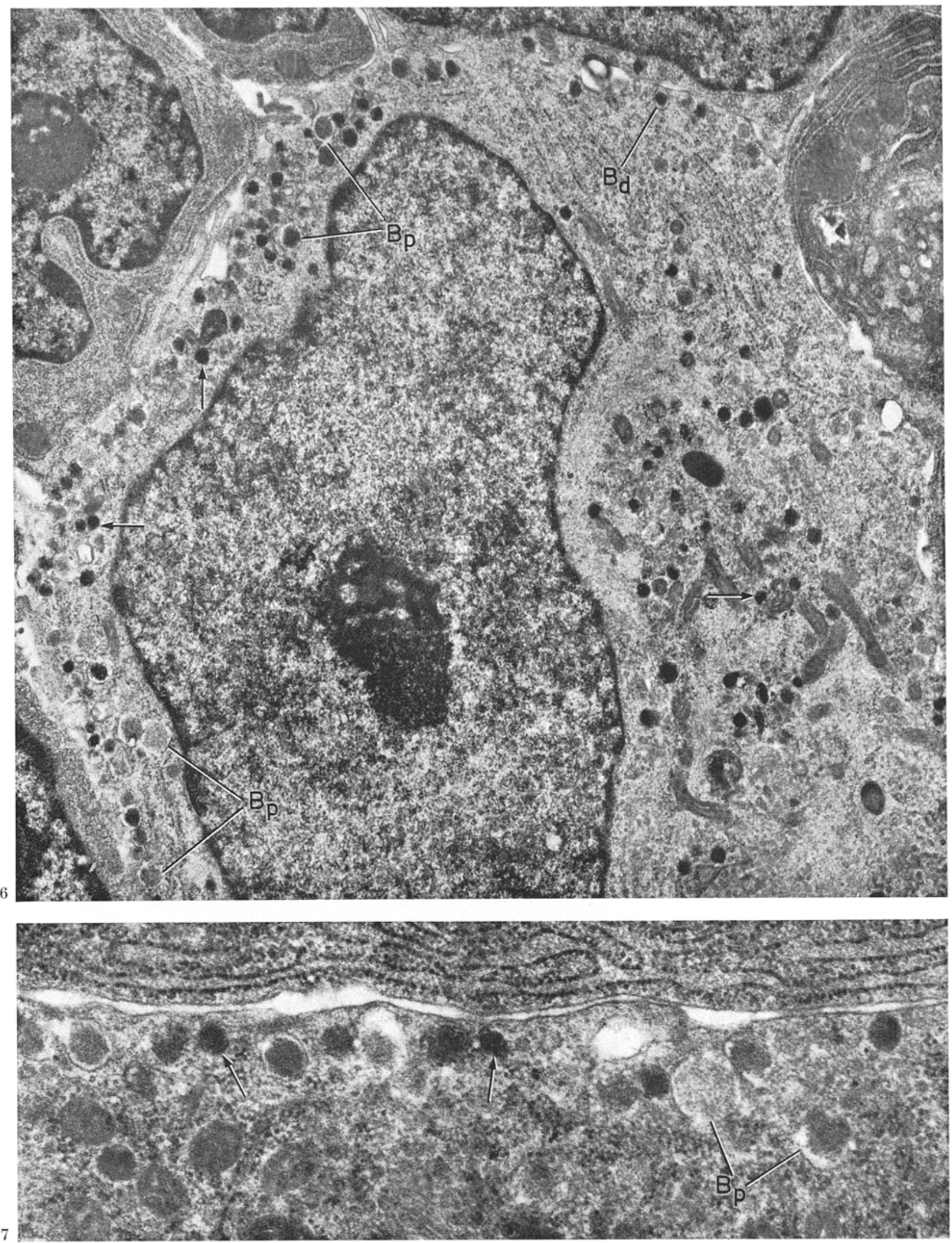

Fig. 6. B cell of 24-day rabbit embryo with pale $\left(B_{p}\right)$ and a few dark $\left(B_{d}\right)$ secretory granules. In addition, several small dark granules lacking a clear halo are seen $(\rightarrow)$. Glutaraldehyde- $\mathrm{OsO}_{4}$ fixation. $\times 14900$

Fig. 7. Higher magnification of the pale $\left(B_{p}\right)$ and small dark $(\rightarrow)$ secretory granules of the $\mathbf{B}$ cell in the 24-day rabbit embryo. $\times 39600$ 
granule core is considerably less electron dense, and the clear space surrounding its core is much narrower. In general, although the Golgi saccules were chiefly found close to the nucleus, the Golgi complex extended peripherally towards the cell border. Epithelial filaments frequently formed a conspicuous band near the nucleus, but were also spread diffusely throughout the cytoplasm.

Except for the relative absence of pale secretory granules, adult $\mathrm{B}$ cells fixed in $\mathrm{OsO}_{4}$ generally resembled the glutaraldehyde- $\mathrm{OsO}_{4}$-fixed $\mathrm{B}$ cells. In addition to dense granules, there appeared a number of membranous sacs, usually empty, but occasionally seen to contain faint osmiophilic material. These sacs have been interpreted in the past as pale $\mathbf{B}$ granules [3, 22].

In the remainder of this work, the ultrastructural descriptions refer to glutaraldehyde- $\mathrm{OsO}_{4}$-fixed tissue, unless otherwise stated. these B cells were almost exclusively of the pale type and gradually increased in number with age. However, even in 32-day-old embryos, exceedingly few B cells were fully granulated and margination was still very common.

The proportion of dark to pale $B$ granules increased with age. Pale B granules not only predominated in embryos but also in neonates up to the second month after birth (Fig. 10). Finally, by 8 months post partum (about $5 \mathrm{~kg}$ ), the dark B granules constituted about $50 \%$ of the total B granule population, a percentage similar to that of the adult pancreas.

Variations in granule appearance occurred in adult as well as in foetal and neonatal rabbits. Differences in the electron density of the pale B granules were often noted, and the cores of dark B granules were sometimes seen to have angular borders or to be organized as crystal-like profiles.

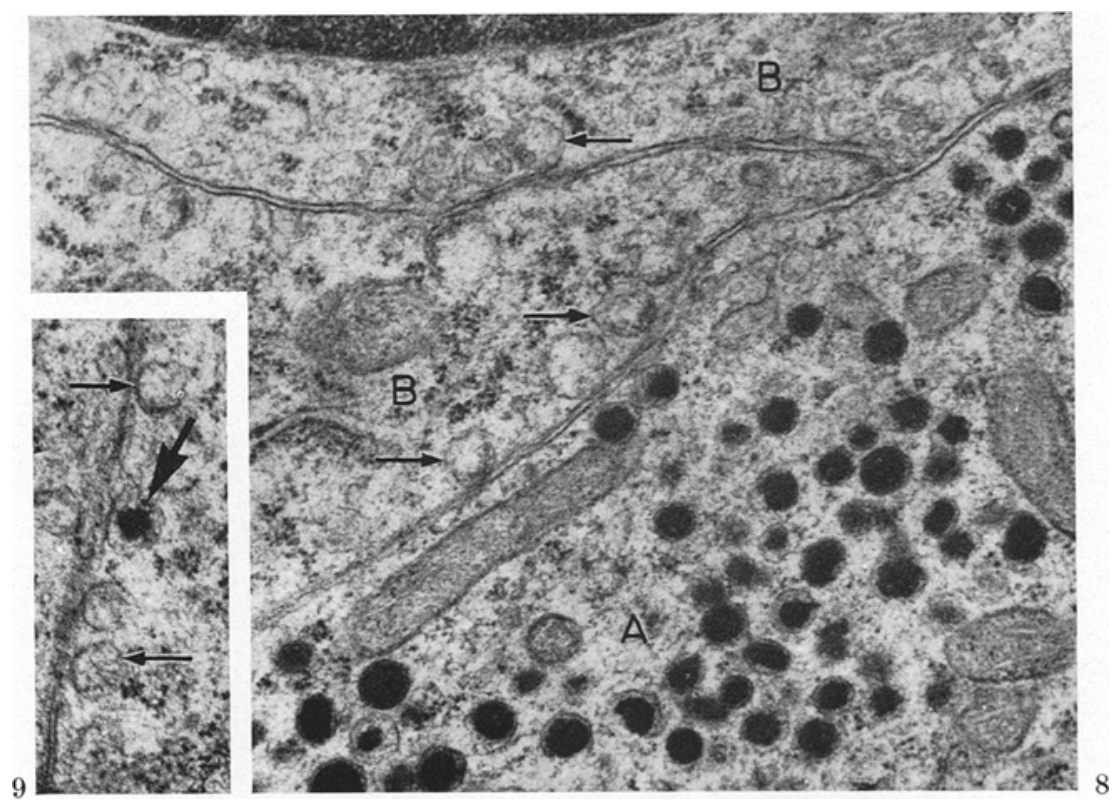

Fig. 9. 24-day embryo. B cell border with empty membranous sacs $(\rightarrow)$ similar to those of Fig. 11 and one B granule with a dense core $(\rightarrow) . \mathrm{OsO}_{4}$ fixation. $\times 24500$

The scattered B cells found in 24- and 25-day-old embryos contained both dark and pale granules like those of the adult (Figs. 6, 7). However, many dark granules were found which differed in appearance from those of older animals; they lacked the large clear halo and, in general, seemed to be smaller in diameter (Figs. 6, 7). These granules were very rarely found in embryos over 26-days. Like the pale granules, they were not preserved by $\mathrm{OsO}_{4}$ alone (Figs. 8, 9). Most $\mathrm{B}$ granules, regardless of type, were situated close to the cell membrane. This preferential location of the B granules was in agreement with the light microscopic observations.

The great majority of $\mathrm{B}$ cells of 26-day and older embryos were located in distinct islets. The granules of
Fig. 8. 24-day embryo. Portion of $A(A)$ and $B(B)$ cells. Empty membranous sacs $(\rightarrow)$ line the borders of the $\mathrm{B}$ cells. $\mathrm{OsO}_{4}$ fixation. $\times 24500$

Unique to the $\mathrm{OsO}_{4}$-fixed pancreas from embryos and neonates up to two months old were a great number of empty membranous sacs in the $\mathrm{B}$ cells (Fig. 11). The limiting membrane of these sacs was often discontinuous. There appeared to be a close topographical correlation between these empty sacs and the pale $B$ granules found in glutaraldehyde$\mathrm{OsO}_{4}$-fixed material (Figs. 10, 11).

Cell shape and cytoplasmic density varied considerably in B cells of animals up to one month old (Fig. 12). As eapillarization of the islets progressed, these differences decreased so that the $B$ cell population eventually resembled that of the adult rabbit.

Microvilli and the accompanying enlargement of intercellular spaces were very common among islet 


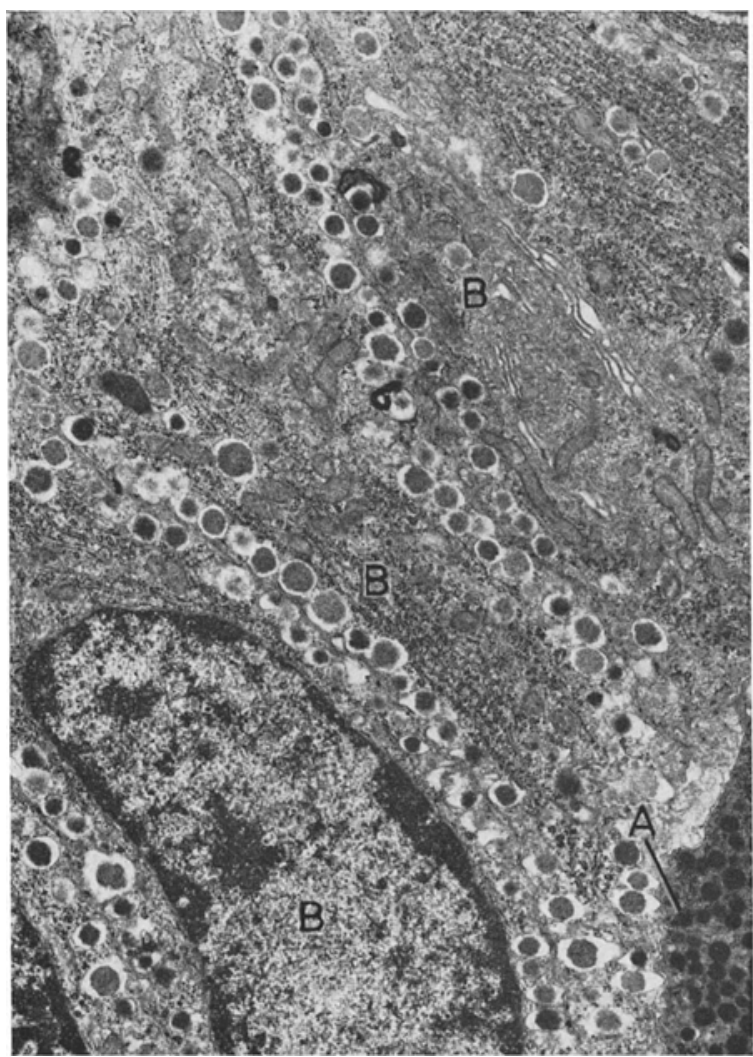

Fig. 10. 11 days post partum. Prominent margination of $B$ granules. The majority of these granules are of the pale type. B cells (B). A cells (A). Glutaraldehyde-OsO

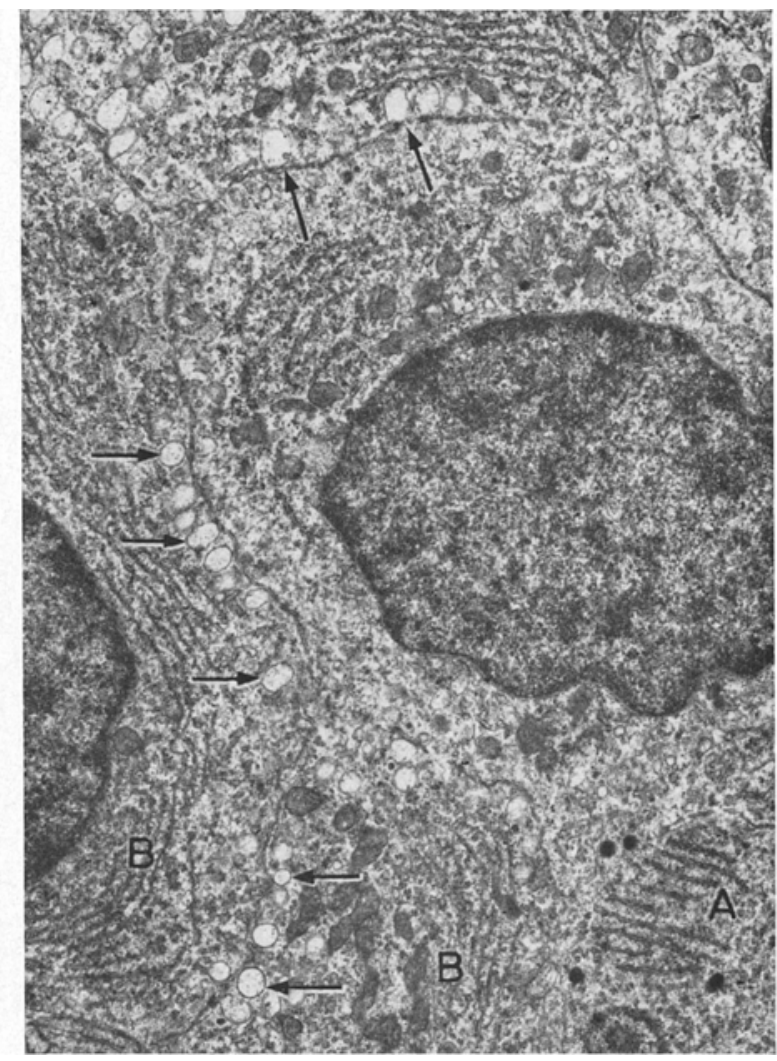

Fig. 11. 11 days post partum. Margination of empty membranous sacs $(\rightarrow)$ in $\mathrm{B}$ cells $(\mathrm{B})$. A cell (A). $\mathrm{OsO}_{4}$ fixation. $\times 9500$

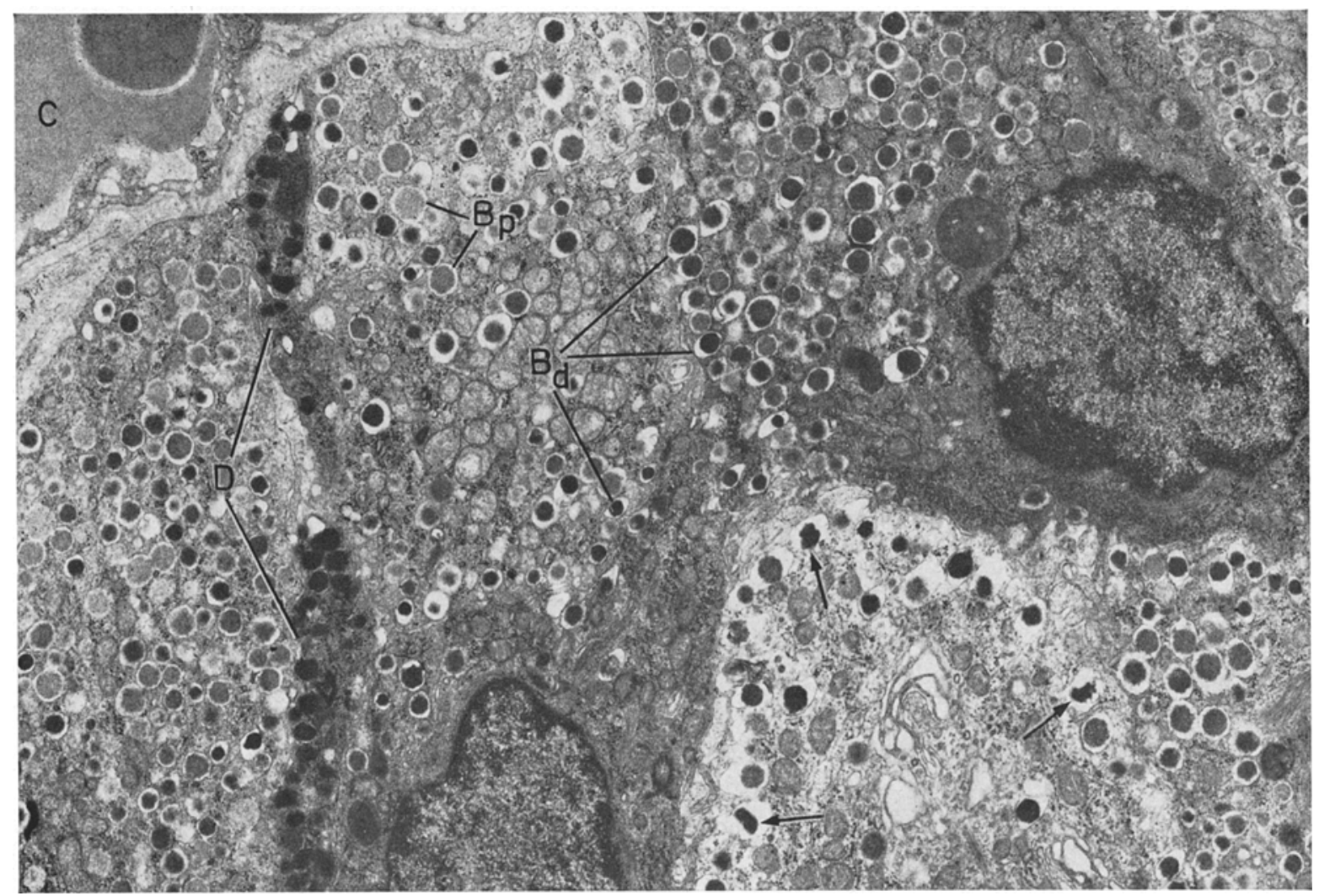

Fig. 12. 21 days post partum. Variations in B cells cytoplasmic density. Although pale B granules $\left(B_{p}\right)$ predominate, several dark B granules $\left(B_{d}\right)$ and a few crystalloid cores $(\rightarrow)$ are seen. Portion of $\mathrm{D}$ cell $(\mathrm{D})$. Capillary (C). Glutaraldehyde-O $\mathrm{sO}_{4}$ fixation. $\times 7000$ 
cells in the foetus and in rabbits up to one month old. These features progressively decreased with age so that they were considerably less frequently encountered in animals over 200 days of age.

Some mitochondria or portions of mitochondria were sometimes swollen in the B cells of the young foetus. Swelling was less conspicuous by the second week after birth. Myelin figures of varying sizes were often associated with mitochondria as well as with other organelles including the B secretory granules.

Free ribosomes and stacks of rough endoplasmic reticulum cisternae were common in very young animals, where granules were few and mainly situated in the periphery of the cytoplasm (Figs. 10, 11). Within the cisternae of the endoplasmic reticulum, there was a flocculent material of low electron density. In a few B cells, fusion of parallel endoplasmic reticulum membranes occurred as previously demonstrated in $\mathrm{B}$ cells of cortisone-treated adult rabbits [3] and in vitamin $\mathrm{C}$-induced diabetes in the rat [32]. This fusion was also seen in $\mathrm{OsO}_{4}$-fixed tissues. The Golgi apparatus appeared to be less prominent in $B$ cells of young animals than in those of the adult.

Epithelial filaments were present in all islet cell types of all ages studied. They were, however, most abundant in B cells. The distribution and fine structure of these epithelial filaments were similar to those described previously for adult rabbits [3]. Multitubular bodies [31] as well as microtubules did not appear to differ strikingly in number or distribution with age.

$A$ and $D$ cells could be distinguished from $B$ cells in all animals studied on the basis of the fine structure of their secretory granules. In foetal A cells, regardless of which fixation technique was used, the dark granule core was often surrounded by an area of slightly less electron density (Fig. 8).

\section{In Vitro Study}

Tables $1-3$ and Fig. 13 summarize the results of the insulin release experiments in vitro on the three age groups. It can be seen that each of the three groups responded significantly to the two independent, high glucose stimulation tests, and that the insulin secretion during the fourth period returned to the pre-stimulation level.

In paraffin sections of incubated pancreas, areas of necrosis comprised approximately $5-50 \%$ of the tissue. In general, however, about $20 \%$ was affected. Cells, including islet cells in the necrotic areas appeared completely disrupted. The $\mathrm{B}$ cell population in islets from undamaged areas consisted of normal-appearing cells and a few isolated necrotic cells. In none of the B cells was there a significant change in aldehyde-fuchsin positivity or granule distribution. The appearance of the incubated pancreas did not seem to depend on the glucose concentration of the incubation media.

By electron microscopy, islets from non-damaged areas, as recognized by toluidine blue and aldehydefuchsin stains, contained a large proportion of normal- (a)

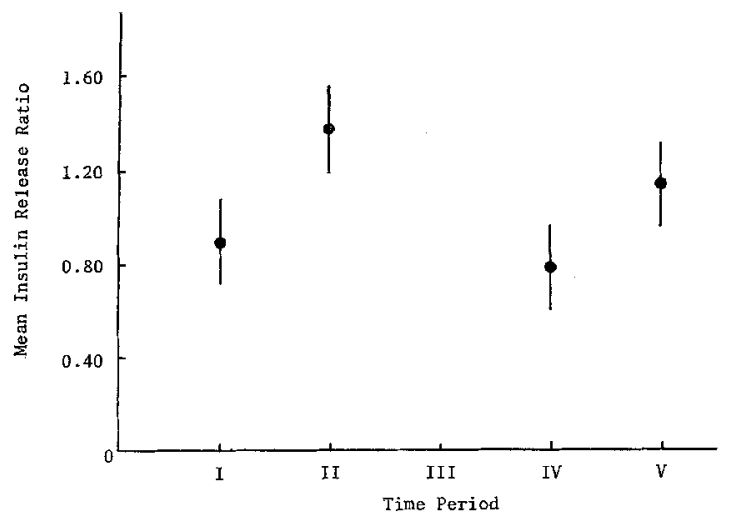

(b)

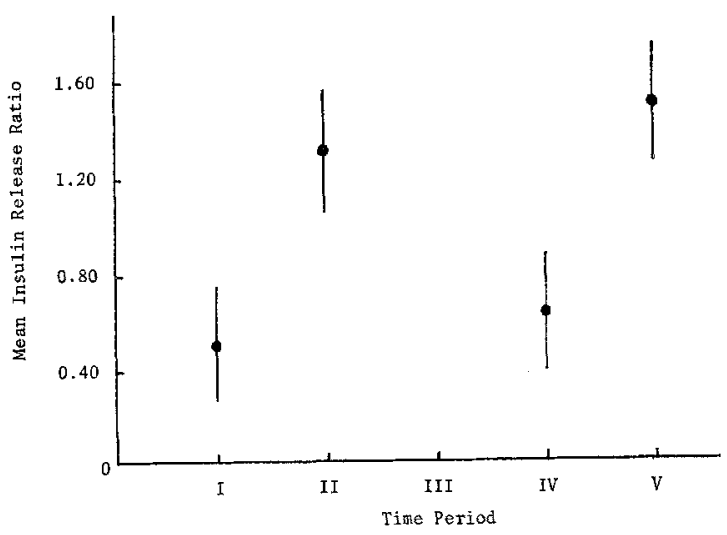

(c)

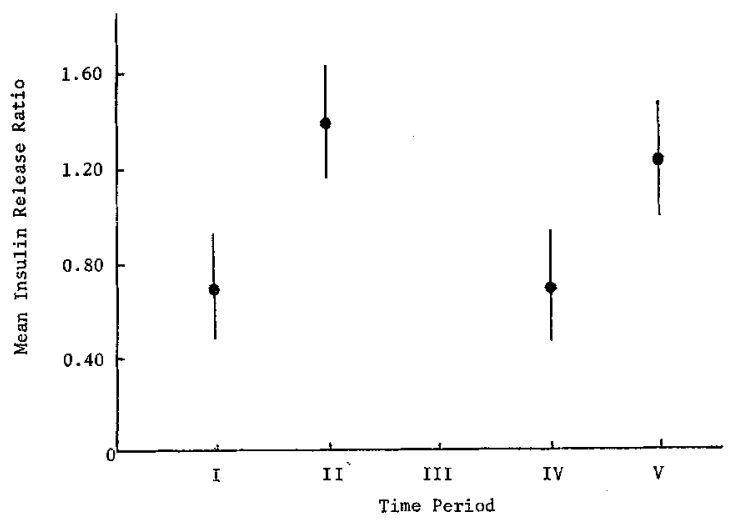

Fig. 13. Mean insulin release ratio $(\bar{R}) \pm$ SEM during 30 min incubation periods from (a) 24-day embryos, (b) 30 day embryos, and (c) adult rabbits. Glucose concentration was $0.3 \mathrm{mg} / \mathrm{ml}$ during the 30 -min preincubation period and time periods I, III, and IV. During time periods II and $V$, the glucose concentration was $4.0 \mathrm{mg} / \mathrm{ml}$. The differences between the $\bar{R}$ 's during time periods I and II are significant $(p<0.005, p<0.001$, and $p<0.001$ for the 24-day embryos, 30-day embryos, and adult rabbits, respectively) as are the differences between the $\bar{R}$ 's during time periods IV and $\mathrm{V}(p<0.01, p<0.001$, and $p<0.005$ for the 24-day embryos, 30-day embryos, and adult rabbits, respectively) 
appearing B cells (Fig. 14), and a few necrotic B cells (Fig. 15). In addition, some $B$ cells contained many small vacuoles, most of which were clearly related to dilated endoplasmic reticulum. These variations in the $B$ cell population appeared to be independent of the glucose concentration of the incubation media.

Study of non-necrotic B cells from the foetal and adult pancreas incubated in either low or high glucose media revealed no obvious changes in aldehydefuchsin positivity, B granule distribution, the proportion of dark to pale granules, the number of dark granules with crystalloid contents, the microtubular or epithelial filament system, or emiocytosis. Although less emphasis was placed on the study of other organelles (endoplasmic reticulum, Golgi complex, lysosomal bodies, mitochondria, nucleus, nucleolus, and cilia), no obvious departure from their normal variations was found.

The necrotic $B$ cells were seen in various stages of disintegration. It is of interest that, despite extensive alterations, most still contained a large number of intact B granules with their limiting membranes. Dark, pale, and crystalloid cores were seen in these granules.

\section{Discussion}

Confusion surrounding the existence of B granules in foetal and neonatal rabbit pancreas has resulted from the different staining properties of Gomori's chrome-alum hematoxylin and aldehyde-fuchsin stains $[2,15,36,37,50]$. Because of its high selectivity for $B$ granules, aldehyde-fuchsin, in contrast with Gomori's hematoxylin, clearly demonstrated $\mathbf{B}$ granules not only in neonatal, but also in the foetal pancreas where such granules were relatively few in number. These results were substantiated by the electron microscopic studies. The appearance of $B$ granules in the young foetus has also been demonstrated by electron microscopy in other species $[8,42,51]$. Such observations justify renewed investigations on the role of the $B$ granule membrane as the primary action site of $\mathrm{Ca}^{2+}$ in insulin release. This possibility was tested and discarded in previous work by others [37] on the assumption that the 27-day rabbit foetus was devoid of B granules.

The predominance of pale B granules in neonatal $[23,50]$ and foetal rabbits was found to gradually decrease with age, and the proportion of dark to pale granules to increase until the normal proportion of $1: 1$ was reached. It seems possible that in growing rabbits the demand for insulin relative to the amount of insulin produced may be too great to allow much storage in the form of dark granules. A similar concept of the predominance of pale granules in actively secreting rabbit $B$ cells, and of the accumulation of dark granules only when insulin secretion is at a low level has been previously proposed [22], and is supported by studies on adult rabbits recovering from severe cortisone degranulation, during which time pale $\mathbf{B}$ granules are the first type formed [3].

In attempts to establish the secretory pathway of insulin release in $\mathrm{B}$ cells, several morphological studies of incubated rabbit pancreas releasing insulin in response to various stimuli have been carried out [7, $9,11,12,26,54]$. So far, however, there is considerable disagreement. Some have reported changes in the stimulated tissue by both light and electron microscopy, such as degranulation, emiocytosis, hyperplasia and vesiculation of ergastoplasm [12] and increased margination of $\mathrm{B}$ granules and emiocytosis [54]. Others were unable to find morphological changes correlating with the increased insulin release [7], even after exhaustive statistical analysis of several ultrastructural parameters [11]. Like the latter two groups, we were unable to substantiate morphologically the increased insulin release (i. e. comparison of stimulated with non-stimulated tissues) in response to glucose challenge in vitro. This was also true in foetal tissue where the $B$ granule population was very small.

Evidence has been given for the release of dark and pale granules by emiocytosis both previously $[3,10$, $12,20,24,32,48,54]$ and in the present work. However, it is unknown whether insulin must pass through a granule stage (i. e. dark or pale granule) prior to being released from the cell or, alternatively, whether it may be released from a soluble pool of insulin [41] contained elsewhere in the cell. It is also possible that one granule type may be released in preference to another. In this respect, it is interesting that, although considerable alterations in the proportion of dark to pale B granules have been achieved in vivo under various experimental conditions in the rabbit $[3,16$, $24,28,38,45,46,48,49]$, similar changes have not been reported in the much shorter term experiments in vitro. Thus, a preferential release of one granule type over another has not yet been established either previously or in the present work.

The B granule cores of most rodents are usually round in profile $[5,27,30,40,41]$. However, B granules with electron-dense crystalloid contents were found in rabbits of all ages. Similar structures have been described in rabbits during the early degranulation and regranulation phases following cortisone-induced hyperglycaemia [3], in rabbits following sulphonylurea treatment [48], and in the spiny mouse during the development of hyperglycaemia [41]. We, therefore, believe that the crystalloid figures may represent both precursor and breakdown forms of the dark B granules. Although crystalloid figures were present in incubated pancreas, there was not an obvious increase in their proportion relative to that of non-incubated tissue from the same animal. Perhaps if the incubation time could be extended or a much greater level of insulin release attained (such as has been reported when organ culture of foetal rat pancreas is stimulated with glucose, caffeine, and potassium [21]), the content of more dark granules might have undergone breakdown 


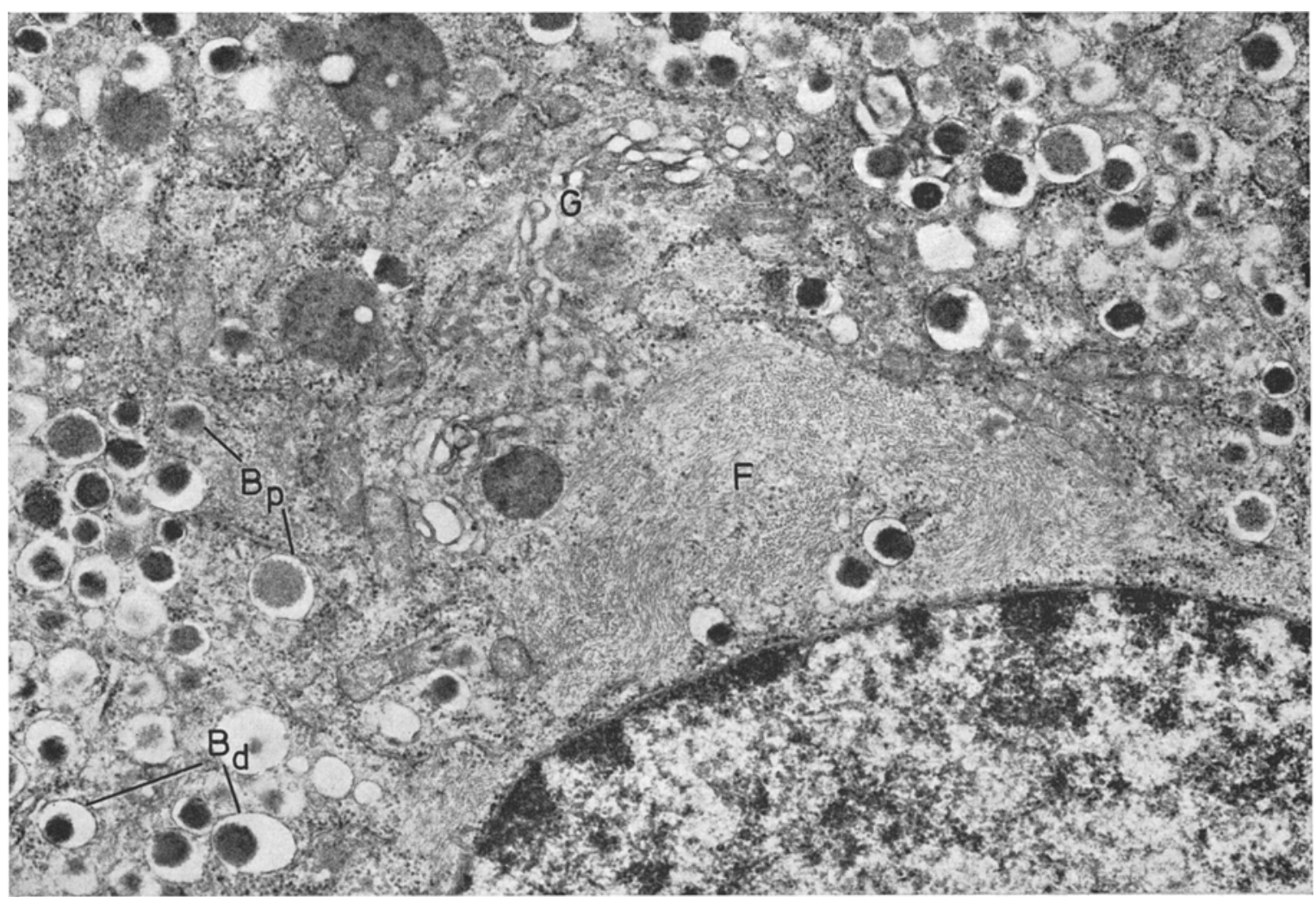

Fig. 14. Normal-appearing B cell from adult rabbit pancreas which has been incubated for a total of $3 \mathrm{~h}$ during which time it underwent high glucose stimulation twice. Dark $\left(B_{d}\right)$ and pale $\left(B_{p}\right)$ secretory granules in normal proportion of approximately $1: 1$. Golgi apparatus (G). Fibrillar material (F). Glutaraldehyde- $\mathrm{OsO}_{4}$ fixation. $\times 18500$

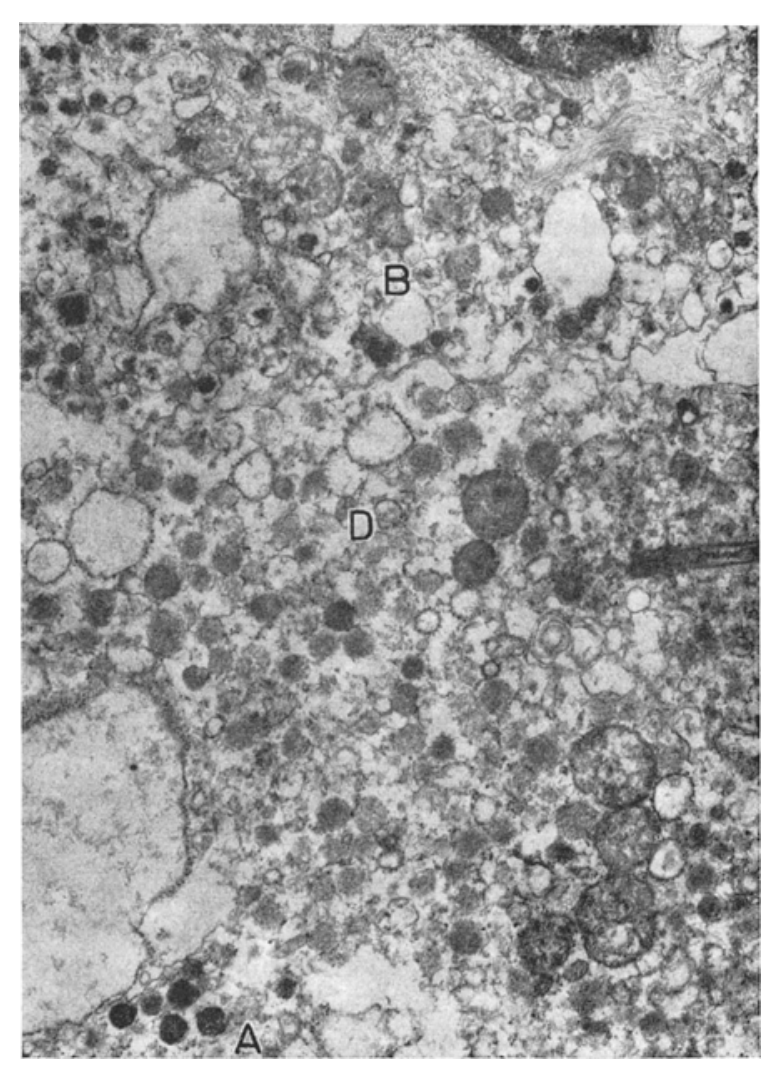

Fig. 15. Portions of necrotic B (B), D (D), and A (A) cells from incubated adult rabbit pancreas. $A$ large number of secretory granules are still present in these cells. Glutaraldehyde- $-\mathrm{SsO}_{4}$ fixation. $\times 7300$ 
and an increased number of crystalloid figures would have been seen.

It is more than of passing interest for biochemical studies that most of the granules of necrotic cells showing extensive disruption remained within the cytoplasm during the period of study. Thus, leakage of $B$ granule contents from necrotic cells into the incubation media is, barring cases requiring extreme accuracy, probably inconsequential to the study of insulin release in vitro. This has been evidenced by the extensive and successful use of this preparation by several investigators. A similar retention of granules by necrotic B cells, as seen by electron microscopy, has been previously noted in vivo in alloxanized rabbits [53] and alloxanized rats [32].

Very recently, the pancreas of the 24- and 30-day rabbit foetuses has been shown to release insulin in vitro in response to glucagon, leucine, ouabain, and potassium [36]. However, in the same work, a response to glucose challenge in vitro was obtained from the 30 -day rabbit foetus, but not from the 24-day foetus. Variations in the in vitro technique seem to be of paramount importance when applied to the 24-day rabbit embryo, since, in contrast with the above lack of response [36], a significant response to glucose challenge was elicited from 24-day embryos in the present study, and appears to have also occurred elsewhere in foetal rabbits of the same age [34].

It is intriguing that whereas foetal pancreas appears to respond to glucose challenge in vitro (e. g. rabbit [37], rat [21]), it does not seem to do so in vivo (e. g. sheep [52], rat [4]). This apparent difference in response by foetal pancreas to glucose challenge will likely remain unclarified until further studies in vitro and in vivo in the same animal are completed.

Acknowledgements. The authors wish to thank Mrs. Vicki Lechago, Miss Karin Nerenheim, Mrs. Janet Hardisty, and Mrs. Bertha Bencosme for their invaluable technical assistance, and Mr. Louis Broekhoven for his statistical advice. - This work was supported by grants from the Medical Research Council of Canada, the Ontario Cancer Treatment and Research Foundation, and the Clare Nelson Bequest.

\section{References}

1. Bencosme, S.A.: Studies on the methods of staining the islet cells of the pancreas. Arch. Path. 53, 87-97 (1952).

2. - The histogenesis and cytology of the pancreatic islets in the rabbit. Amer. J. Anat. 96, 103-152 (1955).

3. - Martinez-Palomo, A.: Formation of secretory granules in pancreatic islet $B$ cells of cortisone-treated rabbits. Lab. Invest. 18, $746-756$ (1968).

4. Cahill, G.F.: In discussion of "Organ Culture of fetal rat pancreas: effect of tolbutamide, glucagon and other substances" by Lambert et al. In Tolbutamide ... after ten years. Proceedings of the Brools Lodge Symposium, p. 81. New York: Excerpta Medica Foundation 1967.

5. Caramia, F., Munger, B.L., Lacy, P.E.: The ultrastructural basis for the identification of cell types in the pancreatic islets. I, Guinea pig. Z. Zellforsch, 67, $533-546(1965)$
6. Coore, H.G., Randle, P.J.: Regulation of insulin secretion studied with pieces of rabbit pancreas incubated in vitra. Biochem. J. 93, $66-78$ (1964).

7. Creutzfeldt, W., Frerichs, H., Creutzfeldt, C. : Studies with tolbutamide on islet tissue in vitro and islet homografts. In Tolbutamide ... a after ten years. Proceedings of the Brook Lodge Symposium, p. 34-48. New York: Excerpta Medica Foundation 1967.

8. Dieterlen-Lièvre, F.: Etude morphologique et expérimentale de la différenciation du pancréas chez l'embryon de poulet. Bull. Biol. France Belg. 99, 3$116(1965)$.

9. Erlandsen, S.L., Vance, J.E., Williams, R.H.: The effect of glucose and epinephrine on the granulation of beta cells in isolated islets of Langerhans. Diabetes 17, 322-323 (1968).

10. Ferreira, D.: L'ultrastructure des cellules du pancréas endocrine chez l'embryon et le rat nouveau-né. J. Ultrastruct. Res. 1, 14-25 (1957).

11. Findlay, J.A., Gill, J.R., Irvine, G., Lever, J.D., Randle, P.J.: Cytology of $B$-cells in rabbit pancreas pieces incubated in vitro; effects of glucose and tolbutamide. Diabetologia 4, 150-160 (1968).

12. Gomez-Acebo, J., Lopez-Quijada, C., R-Candela, J.L.: Fine structure of B-cell from pancreas pieces incubated in vitro. Diabetologia 2, 110-116 (1966).

13. - Parrilla, R., R-Candela, J.L.: Fine structure of the $A$ and $D$ cells of the rabbit endocrine pancreas in vivo and incubated in vitro. I. Mechanism of secretion of the A cells. J. Cell Biol. 36, 33-44 (1968).

14. Gomori, G.: Aldehyde-fuchsin: a new stain for elastic tissue. Amer. J. clin. Path. 20, 665-666 (1950).

15. Grillo, T.A.I.: The occurrence of insulin in the pancreas of foetuses of some rodents. J. Endocr. 31, 6773 (1964)

16. Grodsky, G.M., Feldman, R., Toreson, W.E., Lee, J.C.: Diabetes mellitus in rabbits immunized with insulin. Diabetes 15, 579-585 (1966).

17. Herbert, V., Lau, K., Gottlieb, C. W., Bleicher, S.J.: Coated charcoal immunoassay of insulin. J. clin. Endoer. 25, 1375-1384 (1965).

18. Krebs, H.A.: Body size and tissue respiration. Bio. chim. biophys. Acta 4, 249-269 (1950).

19. Lacy, P.E.: Electron microscopic identification of different cell types in the islets of Langerhans of the guinea pig, rat, rabbit and dog. Anat. Rẹc. 128, 255$267(1957)$

20.- Cardeza, A.F., Wilson, W.D.: Electron microscopy of the rat pancreas. Effects of glucagon administration. Diabotes 8, 36-44 (1959).

21. Lambert, A.E., Orci, L., Jeanrenaud, B., Rouiller, Ch., Renold, A.E.: Organoculture de pancréas foetal de rat: étude morphologique et libération d'insuline "in vitro". In Journées de diabétologie hôtel-dieu 1969 , p. 115-129. Paris: Flammarion 1969.

22. Lazarus, S.S., Brancato, P., Shapiro, S., Volk, B.W.: Cytology of insulin secretion in rabbit. In Tolbutamide ... after ten years. Proceedings of the Brook Lodge Symposium, p. 83-99. New York: Excerpta Medica Foundation 1967.

23. - Shapiro, S.H., Volk, B.W.: Morphology of pancreatic $B$ cell secretion in neonatal rabbits. Lab. Invest. 16, 330-341 (1967).

24. - Volk, B.W.: Ultramicroscopic and histochemical studies on pancreatic beta cells stimulated by tolbutamide. Diabetes 11 suppl., 2-11 (1962).

25. Lechago, J., Bencosme, S.A.: Morphologic heterogeneity in the granule population of pancreatic beta cells in several species. Amer. J. Path. 52, 43a (1968).

26. Lever, J.D., Findlay, J.A., Randle, P.J., Gill, J.R. Evidence for islet cell survival during the short-term maintenance of rabbit pancreas in vitro. J. Anat. (Lond.) 99, 934 (1965). 
27. Like, A.A., Miki, E.: Diabetic syndrome in sand rats. IV. Morphologic changes in islet tissue. Diabetologia 3, $143-166$ (1967).

28. Logothetopoulos, J., Davidson, J.K., Haist, R.E., Best, C.H.: Degranulation of beta cells and loss of pancreatic insulin after infusions of insulin antibody or glucose. Diabetes 14, 493-500 (1965).

29. Luft, J.H.: Improvements in epoxy resin embedding methods. J. biophys. biochem. Cytol. 9, 409-414 (1961).

30. Luse, S.A., Caramia, F., Gerritsen, G., Dulin, W.E.: Spontaneous diabetes mellitus in the Chinese hamster: an electron microscopic study of the islets of Langerhans. Diabetologia 3, 97-108 (1967).

31. Martinez-Palomo, A., Bencosme, S.A.: Multitubular body in rabbit B-cells. J. Microscop. 5, 259-264 (1966).

32. Merlini, D., Caramia, F.: Effect of dehydroascorbic acid on the islets of Langerhans of the rat pancreas. J. Cell Biol. 26, 245-261 (1965).

33. Meyer, J., Bencosme, S.A.: The fine structure of normal rabbit pancreatic islet cells. Rev. canad. Biol. 24, $179-205$ (1965).

34. Milner, R.D.G.: Some studies on the development of the islets of Langerhans. University of London: M.D. Thesis 1968 .

35. - Plasma and tissue insulin concentration in foetal and postnatal rabbits. J. Endocr. 43, 119-124 (1969)

36. - The secretion of insulin from foetal and postnatal rabbit pancreas in vitro in response to various substances. J. Endoer. 44, 267-272 (1969).

37. - Hales, C.N.: The role of calcium and magnesium in insulin secretion from rabbit pancreas studied in vitro. Diabetologia 3, 47-49 (1967).

38. Morgan, C.R., Carpenter, A.M., Lazarow, A.: Effect of insulin antibodies on pancreatic islet insulin and beta granule content. Anat. Rec. 153, 49-54 (1965).

39. Munger, B.L.: The secretory cycle of the pancreatic islet $\alpha$-cell. An electron microscopic study of normal and Synthalin-treated rabbits. Lab. Invest. 11, 885901 (1962).

40. - Caramia, F., Lacy, P.E.: The ultrastructural basis for the identification of cell types in the pancreatic islets. II. Rabbit, dog and opossum. Z. Zellforsch. 67, $776-798$ (1965)

41. Pictet, R., Orci, L., Gonet, A. E., Rouiller, C., Renold, A. E.: Ultrastructural studies of the hyperplastic islets of Langerhans of spiny mice (Acomys cahirinus) before and during the development of hyperglycaemia. Diabetologia 3, 188-211 (1967).
42. Przybylski, R.J.: Cytodifferentiation of the chick pancreas. I. Ultrastructure of the islet cells and the initiation of granule formation. Gen. comp. Endocr. 8, 115-128 (1967).

43. Sabatini, D.D., Benseh, K., Barrnett, R.J.: Cytochemistry and electron microscopy. The preservation of cellular ultrastructure and enzymatic activity by aldehyde fixation. J. Cell Biol. 17, $19-58$ (1963).

44. Stempak, J.G., Ward, R.T.: An improved staining method for electron microscopy. J. Cell Biol. 22, 697701 (1964).

45. Toreson, W.E., Lee, J.C., Grodsky, G.M.: The histopathology of immune diabetes in the rabbit. Amer. J. Path. 52, $1099-1115$ (1968).

46. Tsutsumi, V., Bencosme, S. A., Martin, J.M., Akerblom, H.K.: Ultrastructure of $B$ cells in rats with elevated levels of circulating growth hormone due to MtT-W15 tumour. Anat. Rec. 163, 277-278 (1969).

47. Venable, J.H., Coggeshall, R.: A simplified lead citrate stain for use in electron microscopy. J. Cell Biol. 25, 407-408 (1965).

48. Volk, B.W., Lazarus, S.S.: B cell hyperfunction after longterm sulfonylurea treatment. Arch. Path. 78, $114-126(1964)$.

49. - - Wellman, K.F.: Beta cell structure in latent and chronic diabetes of the rabbit. Diabetes 14, 792804 (1965).

50. Wellmann, K.F., Volk, B.W., Lazarus, S.S., Brancato, P.: Pancreatic B cell morphology and insulin content of normal and alloxan-diabetic rabbits and their offspring. Diabetes 18, 138-145 (1969).

51. Wessels, N.K., Evans, J.: Ultrastructural studies of early morphogenesis and cytodifferentiation in the embryonic mammalian pancreas. Develop. Biol. 17, $413-446$ (1968).

52. Willes, R.F., Boda, J.M., Manns, J. G.: Insulin secretion by the ovine fetus in utero. Endocrinology 84, $520-527(1969)$.

53. Williamson, J.R., Lacy, P.E.: Electron microscopy of islet cells in alloxan-treated rabbits. Arch. Path. 67, $102-109$ (1959).

54. - - Taylor, K.W.: Electron microscopy of islets of Langerhans in rabbit pancreas slices incubated in vitro. Biochem. J. 102, 928 (1967).

\section{Dr. S.A. Bencosme}

Queen's University of Kingston

Department of Pathology

Richardson Laboratory

Kingston, Ontario, Canada 